\title{
Examining the Sequence of Factors Affecting Student' Tendency to Dropout: a Case Study in Greece
}

\author{
George S. Androulakis ${ }^{1,}{ }^{*}$, Dimitra Ap. Georgiou ${ }^{1}$, Pantelis Kiprianos ${ }^{2} \&$ George Stamelos $^{3}$ \\ ${ }^{1}$ Department of Business Administration, University of Patras, Greece \\ ${ }^{2}$ Department of Educational Sciences and Early Childhood Education, University of Patras, \\ Greece \\ ${ }^{3}$ Department of Education and Social Work, University of Patras, Greece \\ *Corresponding author: Department of Business Administration, University of Patras, Greece. \\ E-mail: gandroul@upatras.gr
}

Received: October 15, 2020 Accepted: December 17, 2020 Published: December 20, 2020

doi:10.5296/ije.v12i4.17835 URL: https://doi.org/10.5296/ije.v12i4.17835

\begin{abstract}
Speaking of the causal spectrum of dropout we are referring to something not simple but highly complex. In this context, the issue of dropping out of studies is considered critical within the area of higher education due to its impact on the individual, the university and the society as a whole. In this study, an effort was made to investigate students' tendency to dropout and to identify the sequence of factors that influence it, as well as its configuration per School. For this purpose, hierarchical regression trees were applied for the factors that compose the dropout index, holistically and separately per school, while for each factor the corresponding hierarchical tree with its items has been analyzed further. The responses of 696 students who have not definitely dropped out of their studies at University of Patras were analyzed. The findings indicate that the factors related to students' academic performance have the greatest impact compared to personal, economical, institutional and social set of factors, on the tendency to dropout. In particular, the perceived level of education, the provision of knowledge as the basis of solving complex real-world problems and student's academic efficacy emerge as the most crucial issues of the academic factorial category in regards to student's tendency to dropout.
\end{abstract}

Keywords: dropout, university, school, higher education studies 


\section{Introduction}

The phenomenon of student dropout seems to have crucial dimensions worldwide and is undoubtedly a European problem (Commission/EACEA/Eurydice, 2013; Kehm et al., 2019; Roso-Bas et al., 2016; Tinto, 2006, 2017). The problem encompasses individual, social and economic aspects, (Mujica et al., 2019). On a political level it poses a major challenge regarding the democratization of higher education that over half a century has been central to the European countries at least.

Student dropout is considered as a challenge in the European Higher Education Area linked tightly to the social dimension of the University. In main Communiqués Ministers is underlined the need towards the realization of efforts aiming to increase the completion rates of university studies, (Bergen Communiqué, 2005; Berlin Communiqué, 2003; Bucharest Communiqué, 2012; Leuven Communiqué, 2009; London Communiqué, 2007; Paris Communiqué, 2018; Prague Communiqué, 2001; Y. Communiqué, 2015).

Nevertheless, the definition of student dropout remains under consideration; different sets of factors and phenomena (Díaz \& De León, 2016) along with the evolution of various approaches such as the educational, individual and the holistic one integrating the above (Bardach et al., 2019) could not either be neglected.

The identification of the factors that explain dropout is significant under both a descriptive spectrum - where the student has dropped out - and a predictive one - effort to anticipate it (Mujica et al., 2019).

Therefore, the purpose of this work is to study the way various factors affect students' tendency to dropout of their studies along with the differentiation observed in the hierarchical sequence the factors appear per university school. In this way, students' tendency to dropout could be further enlightened encompassing practical dimensions a university could emphasize on such as academic issues so strategically capture possible students' tendency to depart from their studies.

The literature is rich on the concept of dropout (Larsen et al., 2013; Montmarquette et al., 2001; Mujica et al., 2019; Shankland et al., 2010; Spady, 1971; Stratton et al., 2008; Suhre et al., 2007; Tinto, 1975, 1998) and is continually enriched having induced the interest of both researchers and policy makers (Balias et al., 2016; Fredricks et al., 2004; Fredricks \&

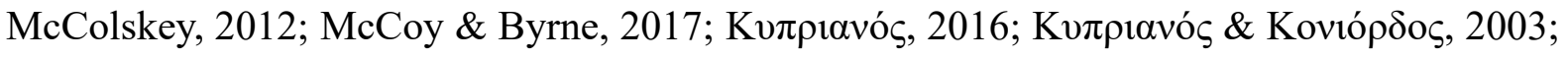

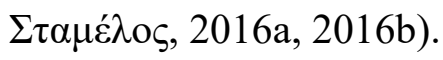

The definition of dropout is as complex as the problem itself. In this regard, university dropout encompasses the phenomenon of stopout where the student interrupts his/her course with the tendency to continue in future (Stratton et al., 2008), the phenomenon of optout where the student alters course or institution (Montmarquette et al., 2001) and the phenomenon of dropout where the student definitively leaves his/her studies in higher education (Mujica et al., 2019).

Nevertheless, its most common interpretation refers to "transfer" to another university school 
or institution (Aina, 2013; Casanova et al., 2018; Heublein, 2014) or alternatively to "permanent" dropout (Casanova et al., 2018; Gury, 2011).

In regards, to the extent diversity of the factors exerted on the phenomenon of dropout, Tinto's (1975) interactionist model (Tinto, 1975) consisted the basis upon which several studies have interpreted the phenomenon from a holistic view, identifying the diverse individual, social, economic and institutional factors that affect students' decision to dropout (García de Fanelli \& Adrogué de Deane, 2015; Mujica et al., 2019).

In the same line of argument, in the literature review variables, phenomena that affect students' dropout such as engagement, burnout, satisfaction, emotional intelligence, motivation, (Astin, 1975; Austin et al., 2005; Kehm et al., 2019; McKenzie \& Schweitzer, 2001; Need \& De Jong, 1998; Pike \& Saupe, 2002; Van Bragt et al., 2007, 2011; Van der Hulst \& Jansen, 2002), as well as categorizations of these factors are also examined. Indicatively, Kim \& Kim (2018) in their study classify the influential factors into four axes: students, professors, resources and university characteristics, (Kim \& Kim, 2018). In the same line of argument, Kori et al. (2015) in their research suggested the following factors' categorization: demographic, student income, academic performance, learning motivation, social integration and institutional characteristics (Kori et al., 2015). Similarly, Díaz \& De León (2016) and Alban \& Mauricio (2019) propose their factorial categorization. Accordingly, the above could be combined as follows:

- Personal Factors: characteristics that define student' behavior such as feelings, thoughts, actions (Alban \& Mauricio, 2019) / Psychological Factors: individual and personality traits such as personal attitudes, behaviors, values, interests, academic success expectations, personality (Díaz \& De León, 2016).

- Academic Factors: university entrance, grades, academic achievements, prior performance, degree of entrance exams (Alban \& Mauricio, 2019) / Integration and Adaptation: university quality characteristics, social integration among students with emphasis on classroom experience, social integration with an emphasis on the relation between students and their professors (Díaz \& De León, 2016).

- Economic Factors: they refer to the ability of students to meet economic requirements along with their studies in regards to material goods and the ability of parents to devote further resources on student academic performance that has a significant impact on their academic achievement (Alban \& Mauricio, 2019). Similarly, according to Díaz \& De León (2016) the Economic Factors are based on the economic model of cost / benefit analysis that takes into consideration the lack of resources to meet costs as well as the need to find employment (Díaz \& De León, 2016).

- Social Factors: the parameters affecting students holistically and are determined by their place and space. The social dimension focuses on the importance of the interaction between students and their social environment, the university, the academic rules and the learning habits (Alban \& Mauricio, 2019) / Sociological Factors: external factors sociological in nature exerted on the student who decides to leave the university, related to family environment, social relationships, peer support, group integration and social environment (Díaz \& De León, 
2016).

- Characteristics of the Educational Institution: factors related to the structural and functional features of the university (Alban \& Mauricio, 2019). According to Díaz \& De León (2016) the Characteristics of the Educational Institution focus on dropout in regards to the university services and qualitative characteristics such as quality of education, vocational counseling, teaching and learning process as well as secretarial support (Díaz \& De León, 2016).

What is also evident from the literature review is that most research is focused either on one factor or the collation of different factors (Astin, 1975; Austin et al., 2005; Kehm et al., 2019; McKenzie \& Schweitzer, 2001; Need \& De Jong, 1998; Pike \& Saupe, 2002; Roso-Bas et al., 2016; Van Bragt et al., 2007, 2011; Van der Hulst \& Jansen, 2002).

Therefore, the present research has a dual purpose reflected through the following research questions:

Research Question 1: what is the hierarchical sequence via which the influential factors affect students' tendency to dropout of studies.

Research Question 2: what is per school the hierarchical sequence of the influential factors on students' tendency to dropout.

\section{Methodology}

The students of the University of Patras make up the statistical population of this study. At the time of the study -May 2019-, the University of Patras comprised twenty-four departments imparted to five Schools having 18,411 students. Moreover, it is the third largest university in Greece and thus is preferable by the prospective students being examined. This results in students' admission from all parts of the country and therefore with proper weighting the sample of Patra's University becomes representative in terms of geographical distribution of its population. For the representativeness of the sample was used the published data of the Hellenic Statistical Authority for the University Sector of Higher Education, (Hellenic Statistical Authority, 2015, no. Table 3). In particular, the admission takes place exclusively via the system of national examinations carried out once a year. Since the admission occurs, the student is not allowed to transfer between different departments, faculties or universities. Therefore, if the student dropouts in order to transfer to another department, school or university, he / she must retake the national exams.

The structured questionnaire was selected at the end of the spring semester in May 2019, on the basis of telephone interviews based on the procedures implemented by the Division of Economic, Social and Quantitative Research of the Laboratory of Information Systems Management and Business Intelligence of the University of Patras. The open source software LimeSurvey, (Limesurvey, 2019), was used to record the responses. After performing the reliability test, 696 completed questionnaires were eventually used in a total of 954 . The sample consists of undergraduate students, $57 \%$ women and $43 \%$ men, coming from: $21 \%$ School of Humanities and Social Sciences, 35\% School of Economics and Business, 6\% 
School of Health Sciences, 17\% School of Natural Sciences and 21\% School of Engineering. The majority of students (86\%) are born from 1995 to 2000 while the rest are born earlier. From the student sample 35\% are freshmen, $22 \%$ second year students, $15 \%$ third year students, $13 \%$ fourth year students, $4 \%$ fifth year students -health science and engineering-, $1 \%$ sixth year medical- students and 10\% students who have exceeded the minimum study time.

In further, the research questionnaire includes the following thematic sections:

- Demographics,

- Student life items,

- Student satisfaction items,

- Student burnout items (Bresó et al., 2007; Demerouti \& Nachreiner, 1998; Hu \& Schaufeli, 2009; Kokkinos, 2006; Reis et al., 2015),

- Emotional intelligence items (Brackett et al., 2006; Goleman et al., 2002, 2013; Petrides, 2009; Schutte et al., 1998)

- Student engagement items (Drennan et al., 2014; Ewell, 2010; Handelsman et al., 2005).

In order to construct a student tendency dropout indicator (will be called dropout indicator), the framework adopted is based on the orientation of factors' categorizations of Diaz et. al (2016) and Alban \& Mauricio (2019) and on factors and phenomena reported in literature as tightly related to dropout (Alban \& Mauricio, 2019; Díaz \& De León, 2016). In particular, Diaz et. al (2016) research the phenomenal categories or types of factors emerged from the models mentioned in literature and on the statements of Braxton et al. (2000) were analyzed as possible factors towards the potential leading to dropout (Braxton et al., 2000; Díaz \& De León, 2016). In the same line of argument, the research of Alban \& Mauricio (2019) accomplished a systematic review of literature on the prediction of university student dropout through data mining technique making an inventory of 112 factors that affect dropout prediction classified into five dimensions.

In the light of the above, the present research applies a sixty-nine-item inventory where the influential factors are categorized as follows:

- Personal factor - Individual characteristics: twenty-seven items including high school urbanity, parental education, items of personal accomplishment, emotional exhaustion, emotional intelligence and student engagement. Twelve out of the twenty-seven items were reversed in order to have a positive correlation with the dropout indicator.

- Academic factor - Academic interaction characteristics: twenty-three items including university school preference order, number of attempts to enter university (national examinations), items of academic performance and interaction and of overall satisfaction with the university. Eighteen out of twenty-three items were reversed.

- Economic factor - Student economic characteristics: five items including -self-assessmentitems on living conditions to meet basic, housing, entertainment, cultural and educational 
needs. All items were reversed.

- Social factor - Student socialization: five items concerning the level of relationship-cooperation among students and their peers and among students and their professors. All items were reversed.

- Institutional factor - Characteristics of the university: nine items concerning student's perceived level of satisfaction with the university functions and infrastructure, the university's support towards the academic success and the overall well-being and promotion of participation in campus events. All items were reversed.

Because the five parts of the questionnaire consist of questions with different scales, item response theory which has the property of the invariance, was applied in order to evaluate uniformly these different scales, (Rupp \& Zumbo, 2004; Zanon et al., 2016).

\section{Results}

For the calculation of the dropout index and for each subfactor category index, the sum of the items of each was applied. All calculations were preceded by normalization. Cronbach's alpha is 0.88 on the dropout index items, 0.80 on the personal index items, 0.76 on the academic, 0.70 on the institutional, 0.72 on the social and 0.87 on the economic index items.

Table 1 contains the correlation coefficients between the dropout index and the five sub-indices that compose it. It is observed the decreasing correlation showing the academic index $(p=0.85)$ followed by the personal $(p=0.81)$, the institutional $(p=0.59)$, the social $(p=0.57)$ and finally the economic $(p=0.45)$. It can be observed that the economic index has the weaker correlation with all the other indices, so it is considered as the most independent.

Table 1. Correlation Coefficients of the Dropout Indicator and Its Subfactors

\begin{tabular}{lcccccc}
\hline & Dropout & Personal & Academic & Economic & Social & Institutional \\
\hline Dropout & 1.00 & & & & & \\
Personal & 0.81 & 1.00 & & & & \\
Academic & 0.85 & 0.51 & 1.00 & & & \\
Economic & 0.45 & 0.28 & 0.24 & 1.00 & & \\
Social & 0.57 & 0.28 & 0.54 & 0.09 & 1.00 & \\
Institutional & 0.59 & 0.23 & 0.48 & 0.17 & 0.38 & 1.00 \\
\hline
\end{tabular}

To find out the sequence of the individual indicators' effect on the dropout index, hierarchical regression trees were applied. This technique is used to interpret a dependent variable from a plurality of interpretive variables in the form of a tree hierarchy, (Breiman, 2017). Regression trees were applied using the Rpart library of R, (Therneau et al., 2018) and the "pruning" procedure was implemented so that cross-validated error rate is minimum, leading thus to an 
optimal hierarchical tree. At the nodes of the hierarchical trees the upper number inside the rectangle refers to the mean value of the dependent variable while the lower number represents the percentage of the population sample corresponding to the branch or leaf. Moreover, where there is a condition when it is true, we are led to the left branch.

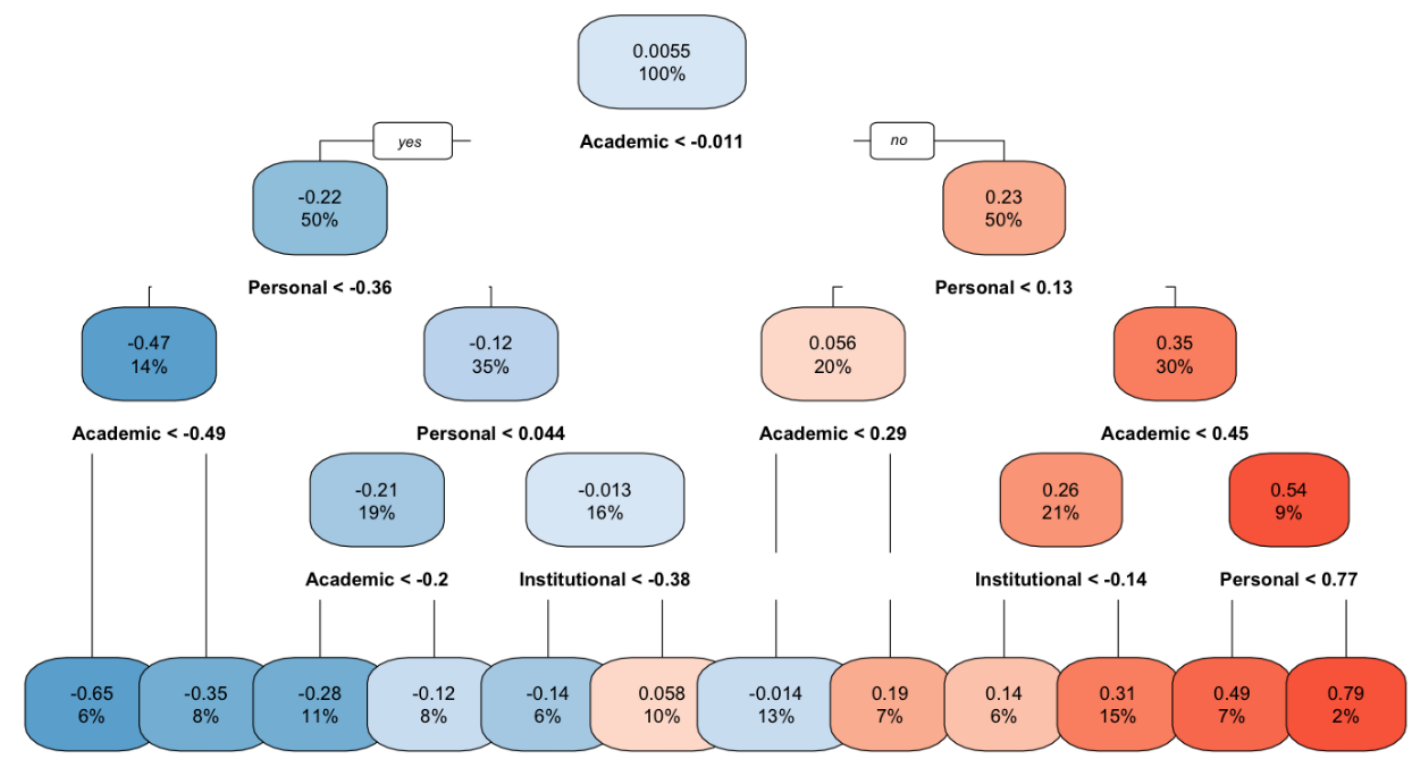

Figure 1. Hierarchical Regression Tree for the Interpretation of Dropout Indicator via the Sub-Indicators

From Figure 1 it can be noticed that the most important indicator is the Academic, which is at the top of the tree (so called root of the tree). At the second level of importance, is the Personal Index. At the third level of importance, for the high values, the Academic index plays the role, while for the low values, both the Academic and the Personal indices do matter. On the fourth level of impact, the Institutional index appears influencing the intermediate values of the Dropout indicator.

Based on the hierarchical tree it can be observed that the Dropout index with an averaged value of 0.79 occurred in $2 \%$ of University of Patras students who show values greater than 0.45 in the Academic index and greater than 0.77 in the Personal index. Because all index values are normalized - and are therefore comparable -, it is found that the Academic index contributes more to lower values on the Dropout index than the Personal. Exactly the opposite situation is presented at the low values of the Dropout index where only the Academic and the Personal indices are included. Nevertheless, at the lower values of the Dropout index the Personal index contributes the most.

Table 2 presents the significance levels of the subfactors in interpreting the Dropout index via the hierarchical regression trees. In column 2, Table 2, is presented the expected subfactorial participation in the Dropout index on the basis of the percentage of items that compose each sub-index in relation to the total number of items. In column 3, Table 2, is presented the 
approximate variable importance based on r-square errors of difference splits of the individual indicators of the hierarchical tree of Figure 1. On the second row of Table 2 are presented the r-squares of the corresponding hierarchical trees per School.

Table 2. Significance of Subfactors in the Interpretation of Dropout Index of the University and per School

\begin{tabular}{lccccccc}
\hline Subfactor & $\begin{array}{c}\text { Expected } \\
\text { value }\end{array}$ & $\begin{array}{c}\text { University } \\
\text { of Patras }\end{array}$ & $\begin{array}{c}\text { Humanities } \\
\text { and Social } \\
\text { Sciences }\end{array}$ & $\begin{array}{c}\text { Health } \\
\text { Sciences }\end{array}$ & $\begin{array}{c}\text { Natural } \\
\text { Sciences }\end{array}$ & $\begin{array}{c}\text { Economics } \\
\& \text { Business }\end{array}$ & Engineering \\
\hline & & $R^{2}=0.80$ & $R^{2}=0.75$ & $R^{2}=0.75$ & $R^{2}=0.70$ & $R^{2}=0.75$ & $R^{2}=0.77$ \\
\hline Personal & 39.13 & 28.97 & 38.21 & 22.92 & 30.13 & 24.66 & 30.25 \\
Academic & 33.33 & 38.65 & 33.98 & 41.15 & 42.96 & 41.86 & 39.27 \\
Economic & 7.25 & 5.96 & 4.85 & 2.65 & 3.77 & 7.42 & 5.83 \\
Social & 7.25 & 13.08 & 12.06 & 15.98 & 12.69 & 13.80 & 12.61 \\
Institutional & 13.04 & 13.34 & 10.89 & 17.31 & 10.45 & 12.25 & 12.04 \\
\hline
\end{tabular}

The same analysis via the hierarchical regression trees illustrated in Figure 2 was applied to each School of the University of Patras. The percentages of variable importance derived from the hierarchical trees in Figure 2, appear respectively in columns 4 to 8 in Table 2. Therefore, it is concluded that:

Based on the values of the Personal subfactor in Table 2, it can be noticed that while its expected participation rate in the formulation of the Dropout index is 39.13\% (division 27 items out of 69), with the exception of School of Humanities and Social Sciences, both the Dropout index and the Schools' indexes participate to a lesser degree. Therefore, the Personal subfactor generally seems to play less role than expected in the Dropout index, as the items composing it present lower values than expected at the University of Patras.

- In regards to the Academic subfactor index while its expected participation rate in the final index is $33.33 \%$ both in the University and in School percentage, with the exception of the School of Humanities and Social Sciences, it appears higher percentages in shaping the overall Dropout index. Combined with the fact that the Academic subfactor emerges as the most significant subfactor in the Dropout index this leads to the direction of the further weakening of the tendency to dropout via the reduction of the Personal index by decreasing the values of the items composing it.

- The Economic subfactor index participates to a lesser degree than expected in shaping the Dropout index, except for the School of Economics and Business. An interpretation that can be given is the fact that the undergraduate education in University of Patras is public and thus free of tuition fees.

- The Social subfactor index - student socialization - participates in a higher almost twice as high compared to the expected-, level as expected in shaping the overall Dropout index. Therefore, by reducing the impact of the items consisting the social subfactor can lead to a lower level of the dropout tendency.

- The Institutional subfactor index participates to a similar with the expected level of 
participation to the overall to Dropout index. Moreover, deviations are observed in individual Schools. Studying the factors the Institutional indicator consists of, items may be revealed that can be improved by each School in order to acquire a lower participation percentage in the Dropout indicator.

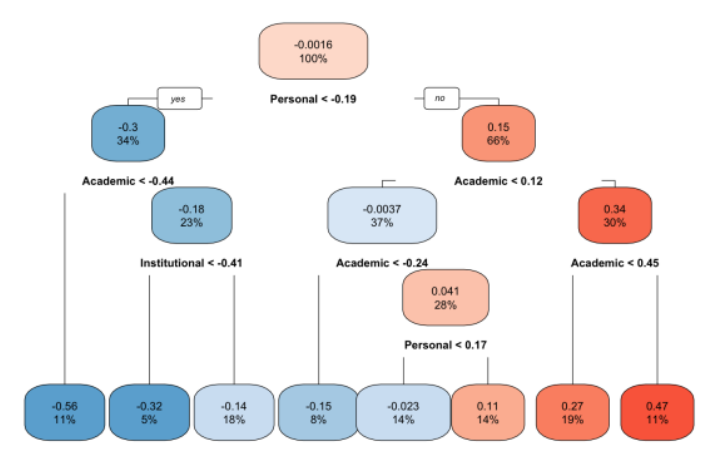

Figure 2a. Hierarchical Regression Tree of Dropout Indicator for School of Humanities and Social Sciences

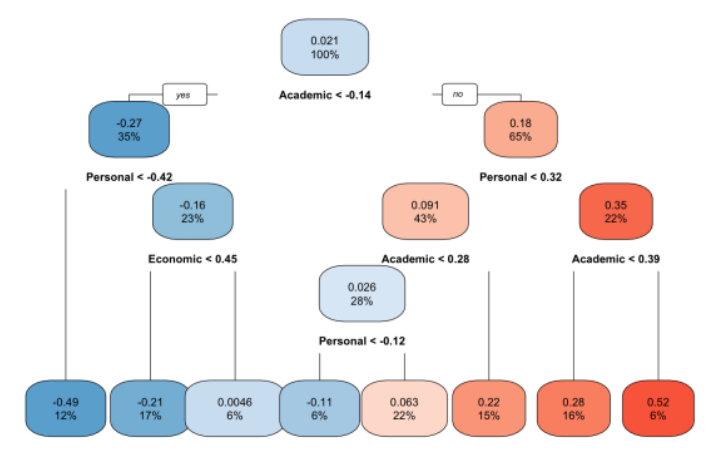

Figure 2c. Hierarchical Regression Tree of Dropout Indicator for School of Natural Sciences

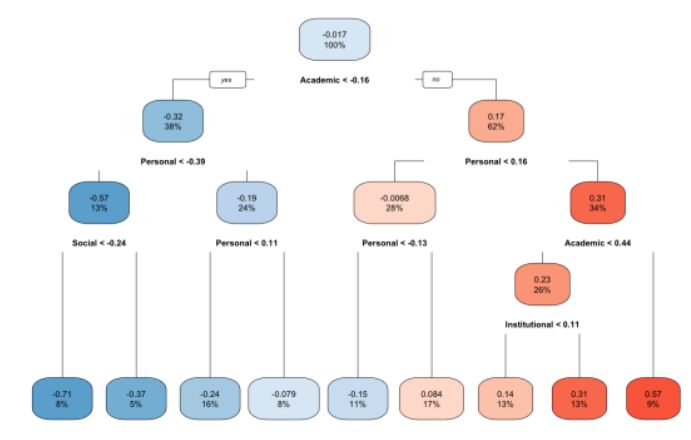

Figure 2e. Hierarchical Regression Tree of Dropout Indicator for School of Engineering

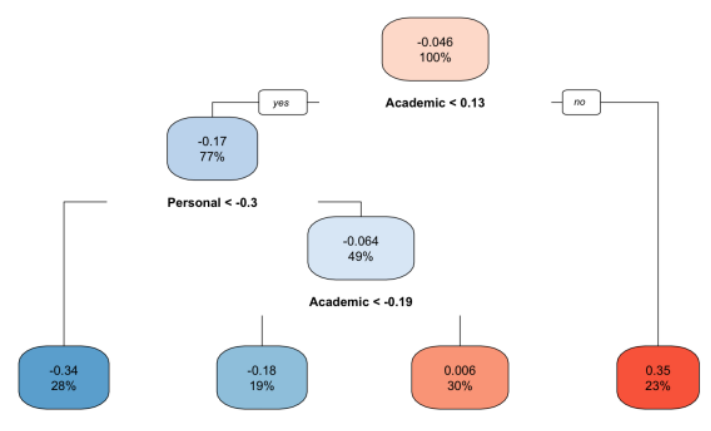

Figure 2b. Hierarchical Regression Tree of Dropout Indicator for School of Health Sciences

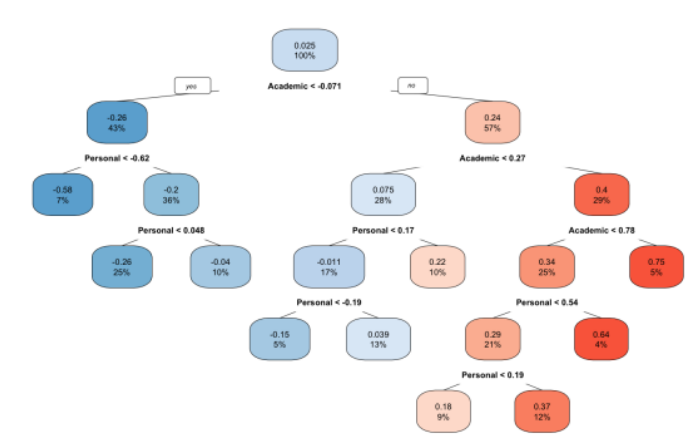

Figure 2d. Hierarchical Regression Tree of Dropout Indicator for School of Economics and Business 


\section{Macrothink

Consequently, from Figure 2 and for each School the following are concluded:

- School of Humanities and Social Sciences: the most important subfactor is the Personal, opposed to the other Schools where the Academic plays the leading role. For both high and low dropout levels, the second most important subfactor is the Academic. The presence of the Institutional subfactor affects both the low and the intermediate values of the Dropout index.

- School of Health Sciences: for the high values of the Dropout index, the Academic subfactor dominates. Nevertheless, for the low values of the Dropout index the second most significant influence comes from the Personal subfactor.

- School of Natural Sciences: the Academic subfactor exerts the most important influence. For both high and low levels of the Dropout index, the Personal subfactor comes second in importance. The third most significant subfactor, exclusively for the low and intermediate values, is the Economic.

- School of Economics and Business: the same sequence of factors appeared in Natural Sciences occurs in the case of School of Economics and Business.

- School of Engineering: the most important subfactor is the Academic, while for both high and low values of Dropout index, the second most important subfactor is the Personal. The third subfactor in significance exclusively for the low values of the Dropout index is the Social while the Institutional subfactor is fourth in importance regarding the intermediate and high values of the Dropout index.

\subsection{Academic Subfactor}

Analyzing the hierarchical regression tree of the Academic subfactor via the interpretive variables of the twenty-three items that compose it, the optimal tree appears in Figure 3. Table 3 shows the items and the corresponding variable importance percentages of the elements appearing on the optimal hierarchical tree imparted to the Academic index.

From Figure 3 it follows that high values of the Academic index occur in $6 \%$ of students of the University of Patras who are not satisfied with their level of study, believe that their university experience has provided them with little or no experience and skills to solve complex real-world problems and have passed half or less of their study courses.

In contrast, low values of the Academic index occur in 3\% of students who are satisfied with their level of study and do not feel that they are working intensively to meet their academic commitments despite receiving adequate feedback by their professors on the completed tasks. 
Table 3. Items of the Academic Index's Hierarchical Regression Tree

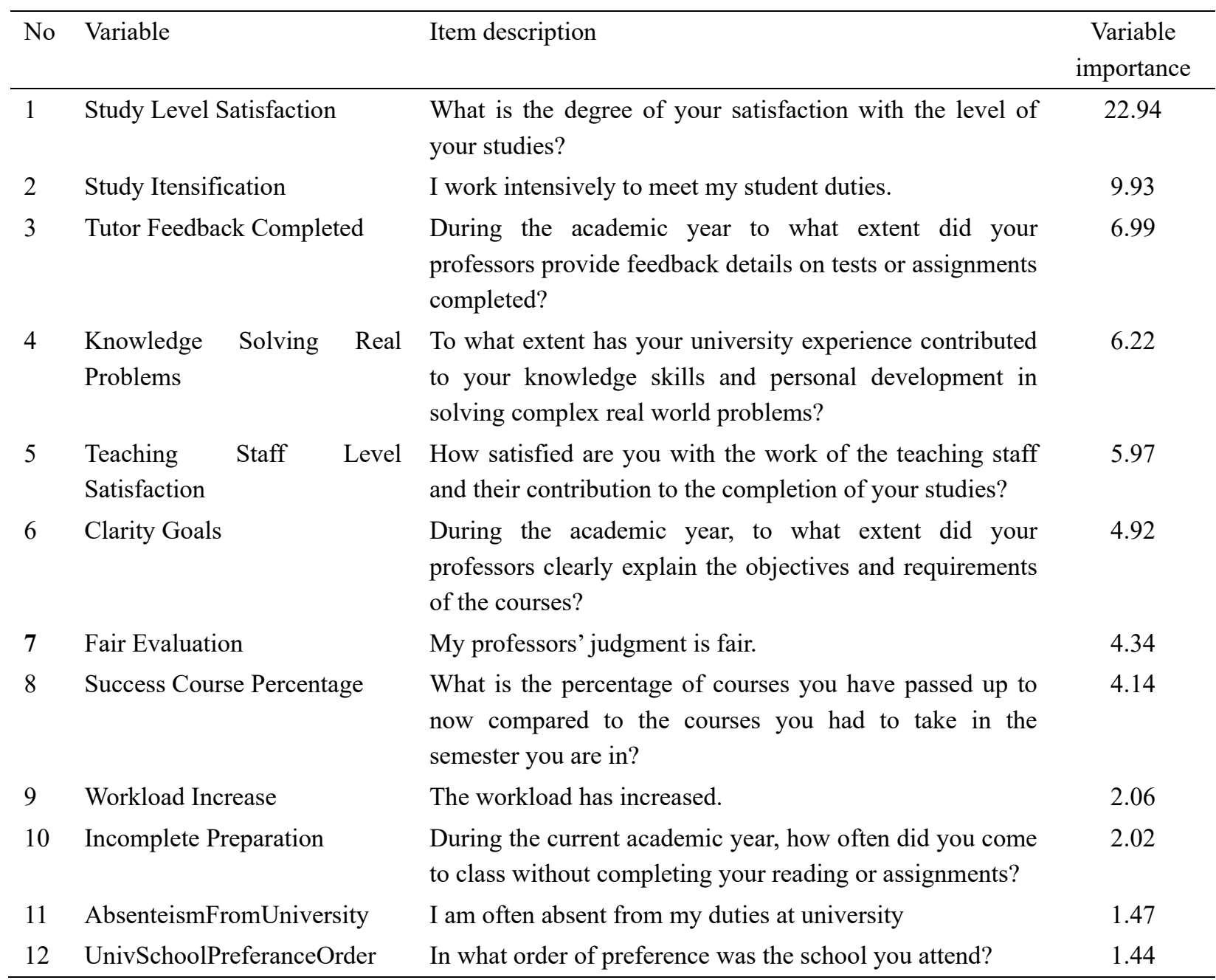

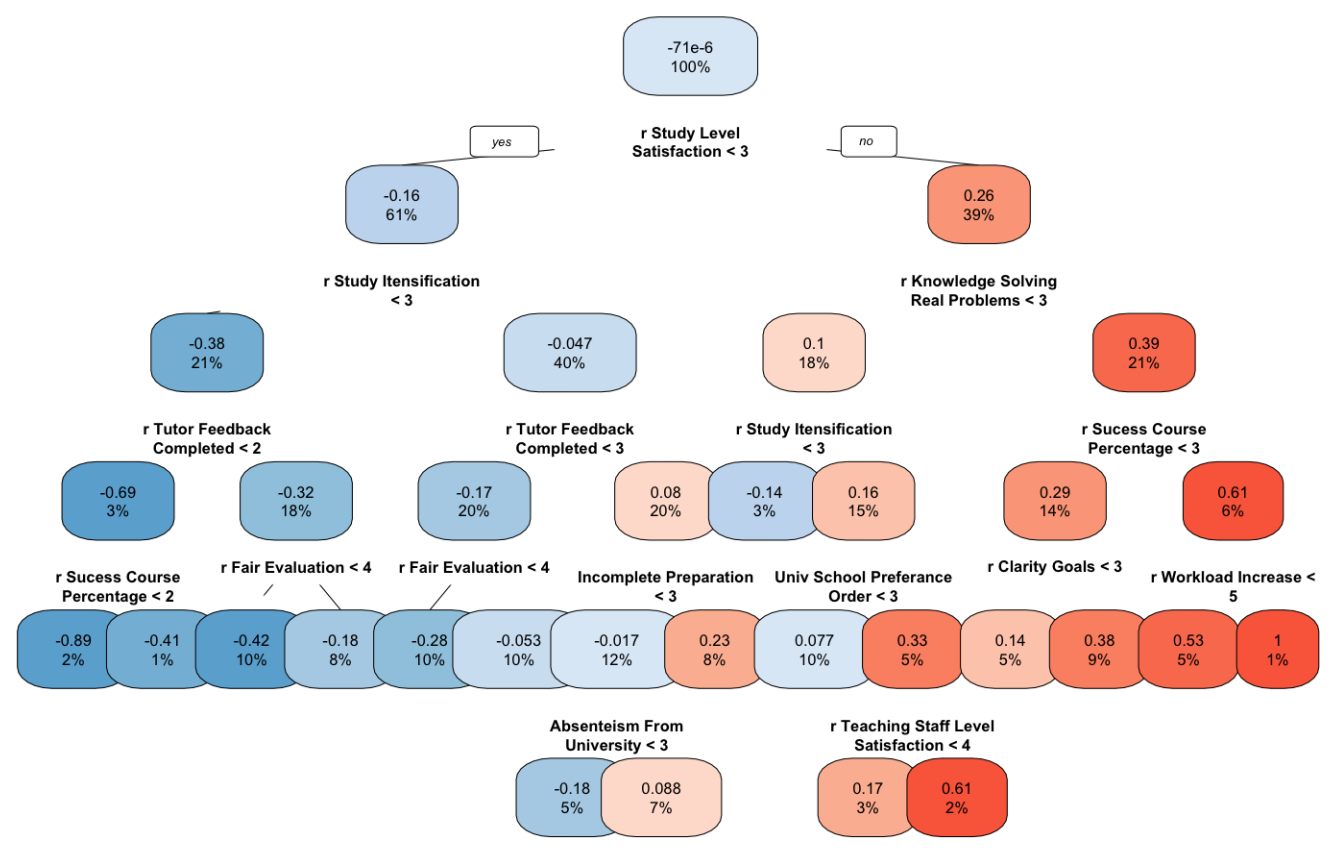

Figure 3. Hierarchical Regression Tree for the Academic Indicator 
Table 4. Level of Satisfaction with Studies per School

\begin{tabular}{lccccc}
\hline School & $\begin{array}{l}\text { Humanities } \\
\text { Social Sciences }\end{array}$ & $\begin{array}{l}\text { Economics } \\
\text { Business }\end{array}$ & $\begin{array}{l}\text { Health } \\
\text { Sciences }\end{array}$ & $\begin{array}{l}\text { Natural } \\
\text { Sciences }\end{array}$ & Engineering \\
\hline 1. Very dissatisfied & 0.69 & 1.65 & 0.00 & 3.42 & 3.36 \\
2. Dissatisfied & 4.14 & 6.2 & 2.33 & 4.27 & 6.04 \\
3. Neutral & 29.66 & 33.06 & 30.23 & 39.32 & 24.83 \\
4. Satisfied & 55.86 & 47.11 & 65.12 & 42.74 & 44.97 \\
5. Very satisfied & 9.66 & 11.98 & 2.33 & 10.26 & 20.81 \\
Mean & 3.70 & 3.62 & 3.67 & 3.52 & 3.74 \\
Standard deviation & 0.73 & 0.84 & 0.57 & 0.87 & 0.97 \\
\hline
\end{tabular}

Table 4 shows the percentages of students by the level of satisfaction per school. For measuring satisfaction, a 5-point scale was used from low to high. It can be noticed that the highest percentage of student responses occurs in option 4 of the 5-point satisfaction scale in all Schools. On the basis of the average, it arises that the greatest level of satisfaction from studies comes from School of Engineering, followed by School of Humanities and Social Sciences, School of Health Sciences, School of Economics and Business and the School of Natural Sciences.

\subsection{Personal Subfactor}

Analyzing the hierarchical regression tree for the Personal subfactor via the interpretive variables of the twenty-seven items that compose it, the optimal tree appears in Figure 4. Table 5 shows the ten items and the corresponding variable importance percentages of the elements appearing on the optimal hierarchical tree belonging to the Personal index.

Table 5. Items of the Personal Index's Hierarchical Regression Tree

\begin{tabular}{|c|c|c|c|}
\hline No & Variable & Item description & $\begin{array}{l}\text { Variable } \\
\text { importance }\end{array}$ \\
\hline 1 & Frustration & I feel frustrated with my studies. & 24.85 \\
\hline 2 & Mental Exhaustion & I feel mentally exhausted with my studies. & 13.69 \\
\hline 3 & Dropout Thought & $\begin{array}{l}\text { I have been thinking about giving up my studies because I feel that } \\
\text { my strengths are running out. }\end{array}$ & 12.39 \\
\hline 4 & Doubt & I doubt the importance of my studies. & 9.35 \\
\hline 5 & Less Interest In Studies & I have been less interested in my studies since my studies began. & 8.99 \\
\hline 6 & Exhaustion & I often feel tired, exhausted, without energy. & 3.21 \\
\hline 7 & Studies Dedication & The university department I attend deserves my dedication. & 2.38 \\
\hline 8 & Understanding Emotion & $\begin{array}{l}\text { Many times I find it difficult to understand exactly what I am } \\
\text { feeling. }\end{array}$ & 1.60 \\
\hline 9 & Notes Repetition & How often do you repeat notes for the next lecture? & 1.47 \\
\hline 10 & Interest Course Material & How interested are you in learning the course material? & 1.00 \\
\hline
\end{tabular}




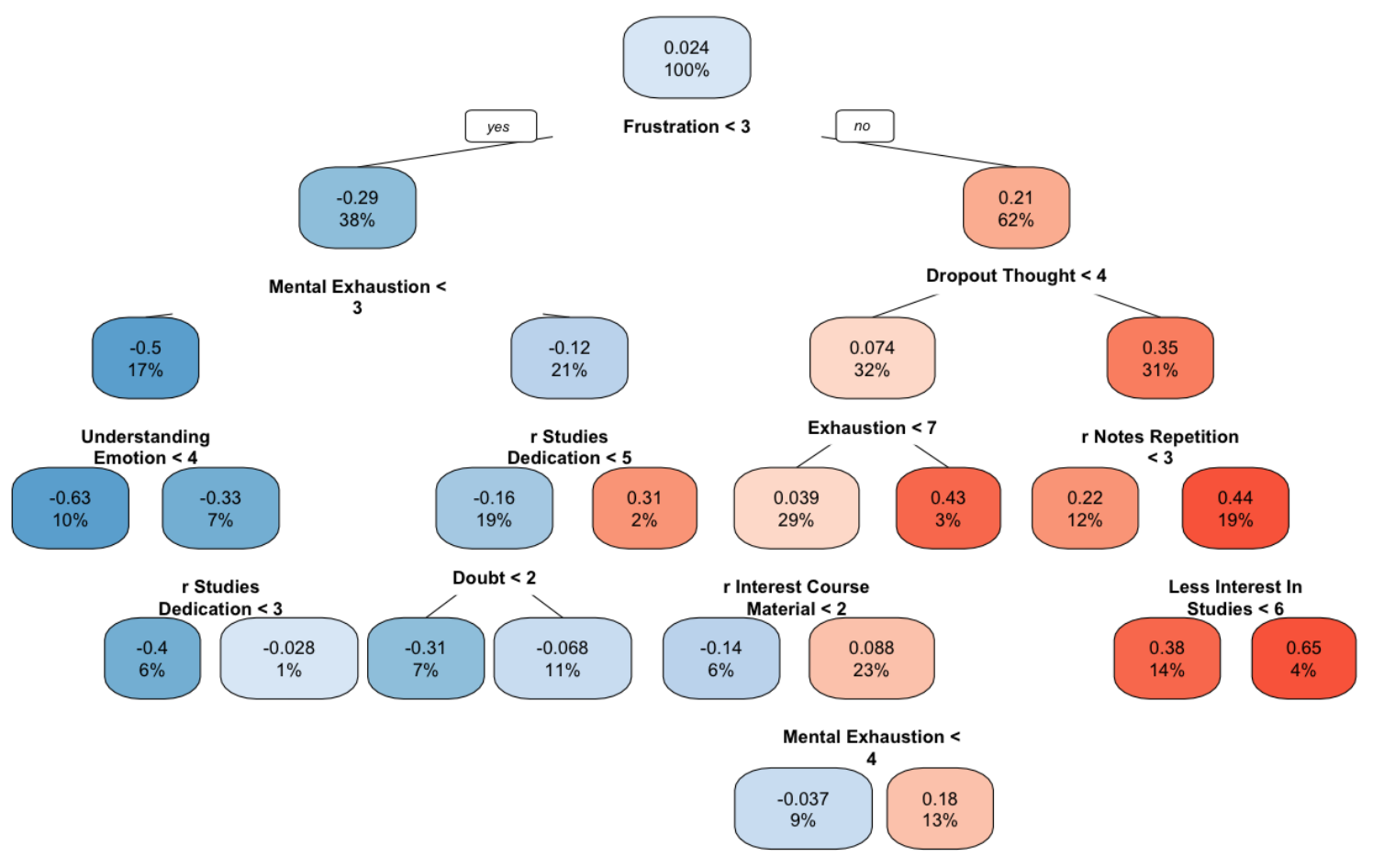

Figure 4. Hierarchical Regression Tree for the Personal Indicator

From Figure 4 is observed that high values of the Personal index appear in $4 \%$ of students at University of Patras who feel frustrated with their studies, have already considered dropping out, rarely or never read notes for repetition and are less interested in their studies compared to the interest they had when they entered the university.

On the other hand, low values on the Personal index occur in $10 \%$ of students who do not feel frustrated with their studies nor they feel mentally exhausted but have difficulty in understanding exactly what they are feeling.

\subsection{Institutional Subfactor}

Figure 5 shows the hierarchical regression tree of the Institutional index using the interpretive variables on the items that compose it. Table 6 shows the six items and the corresponding variable importance percentages of the elements appearing on the optimal hierarchical tree imparted to the Institutional index. 
Table 6. Items of the Institutional Index's Hierarchical Regression Tree

\begin{tabular}{|c|c|c|c|c|}
\hline No & Variable & & Item description & $\begin{array}{l}\text { Variable } \\
\text { importance }\end{array}$ \\
\hline 1 & $\begin{array}{l}\text { Learning } \\
\text { Satisfaction }\end{array}$ & Infrastructure & $\begin{array}{l}\text { The study environment - building infrastructure facilities } \\
\text { - is satisfactory. }\end{array}$ & 25.14 \\
\hline 2 & $\begin{array}{l}\text { University } \\
\text { Success }\end{array}$ & Support for & $\begin{array}{l}\text { To what extent does the University provide assistance for } \\
\text { students' academic success? }\end{array}$ & 16.98 \\
\hline 3 & $\begin{array}{l}\text { Function } \\
\text { Satisfaction }\end{array}$ & Infrastructure & $\begin{array}{l}\text { How much satisfied you are with the entire operating } \\
\text { infrastructure of your department? }\end{array}$ & 13.55 \\
\hline 4 & Support For P & Prosperity & $\begin{array}{l}\text { To what extent does the University provide support for } \\
\text { your overall well-being (recreation, health care, } \\
\text { counseling, etc.)? }\end{array}$ & 12.08 \\
\hline 5 & $\begin{array}{l}\text { Univ Encour } \\
\text { Campus Even }\end{array}$ & $\begin{array}{l}\text { rangement In } \\
\text { nts }\end{array}$ & $\begin{array}{l}\text { To what extent does the University favor the participation } \\
\text { in activities on campus (sports, art, etc.)? }\end{array}$ & 8.27 \\
\hline 6 & $\begin{array}{l}\text { Secretarial } \\
\text { Satisfaction }\end{array}$ & Service & $\begin{array}{l}\text { To what extent are you satisfied with your departments' } \\
\text { secretarial services in relation to the service of the issues } \\
\text { that concern you? }\end{array}$ & 5.17 \\
\hline
\end{tabular}

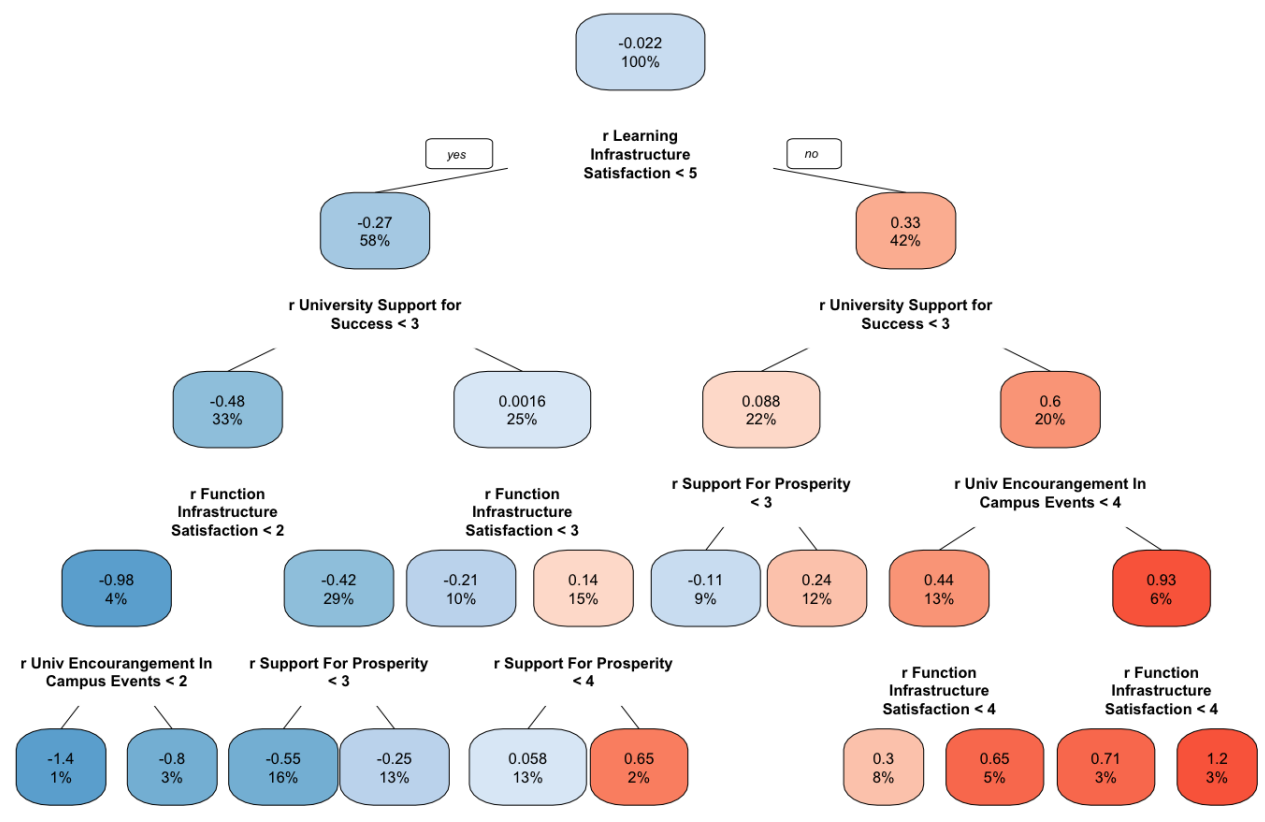

Figure 5. Hierarchical Regression Tree for the Institutional Indicator

The hierarchical regression tree of Figure 5 shows that the most important factor affecting the Institutional subfactor values is the satisfaction with the infrastructure facilities. The second most important factor is students' perception of how well the university is helping towards their academic success followed by the third factor exclusively for the high values of the Institutional index which is their perception of whether the university favors the participation in campus activities. Thought, for the low values of the index, the degree of satisfaction with the operational infrastructure of the department does matter and comes fourth in importance for the high values of the Institutional index. 


\subsection{Social Subfactor}

Figure 6 shows the hierarchical regression tree of the Social index using interpretive variables on the items that compose it. Table 7 shows the five items and the corresponding variable importance percentages of the items appearing on the optimal hierarchical tree imparted to the Social index.

Table 7. Items of the Social Index's Hierarchical Regression Tree

\begin{tabular}{|c|c|c|c|}
\hline No & Variable & Item description & $\begin{array}{l}\text { Variable } \\
\text { importance }\end{array}$ \\
\hline 1 & $\begin{array}{l}\text { Out Of Class Course } \\
\text { Discussion With Tutor }\end{array}$ & $\begin{array}{l}\text { During the current academic year, how often } \\
\text { did you discuss course topics or ideas with a } \\
\text { faculty member outside the classroom? }\end{array}$ & 28.34 \\
\hline 2 & $\begin{array}{l}\text { Career Plans Discussion With } \\
\text { Tutor }\end{array}$ & $\begin{array}{l}\text { During the current academic year, how often } \\
\text { did you discuss your career plans with a } \\
\text { faculty member? }\end{array}$ & 23.19 \\
\hline 3 & Relationship Fellow & $\begin{array}{l}\text { I have a good relationship with my fellow } \\
\text { peers. }\end{array}$ & 17.91 \\
\hline 4 & Relationship Tutor & $\begin{array}{l}\text { I have a good relationship with my } \\
\text { professors. }\end{array}$ & 16.19 \\
\hline 5 & $\begin{array}{l}\text { Cooperation } \\
\text { Preparation }\end{array}$ & $\begin{array}{l}\text { How often have you worked with a fellow } \\
\text { student to prepare for exams or a test? }\end{array}$ & 14.37 \\
\hline
\end{tabular}

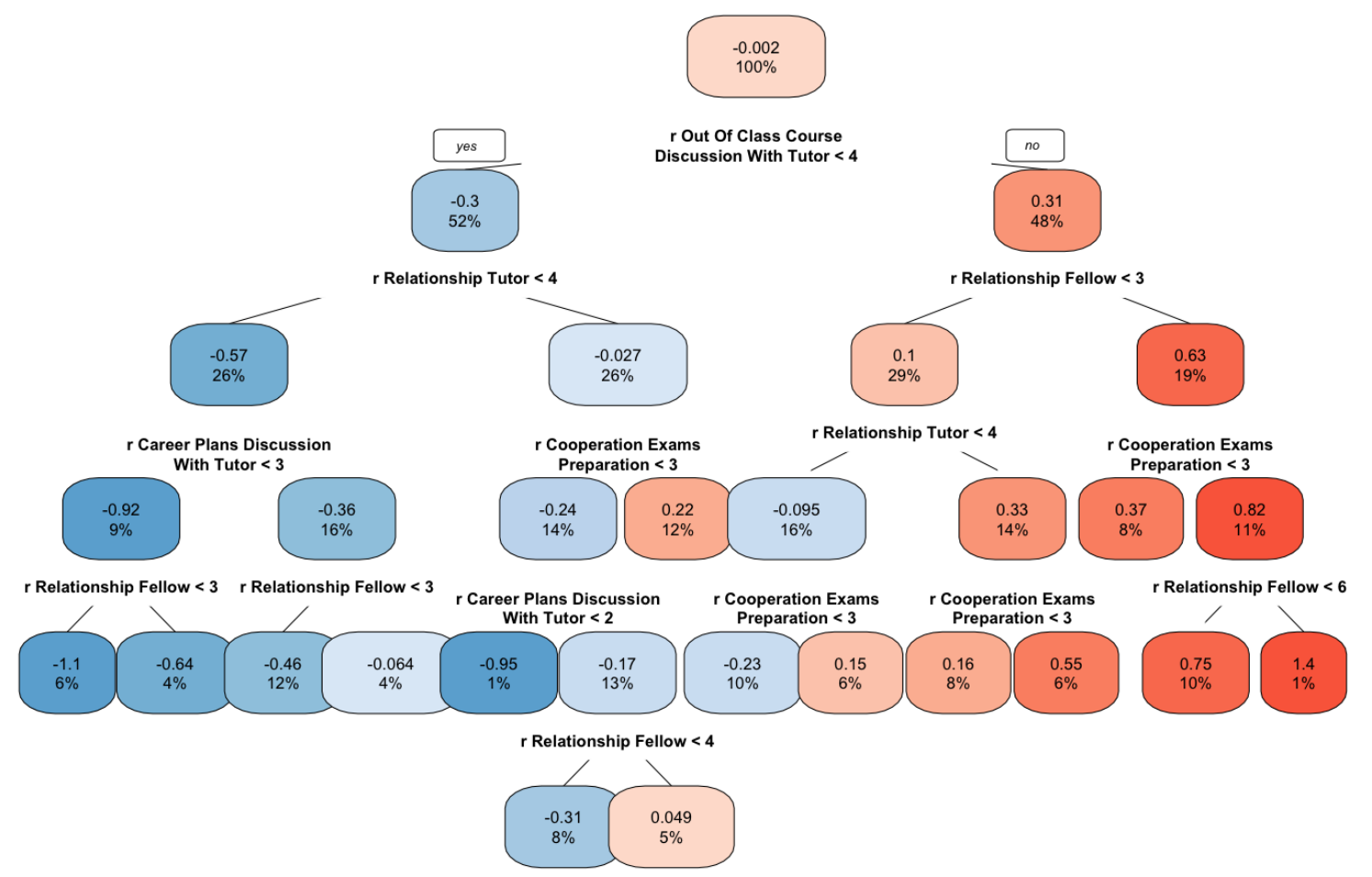

Figure 6. Hierarchical Regression Tree for the Social Indicator 


\section{Al Macrothink Institute ${ }^{\mathrm{TM}}$}

The hierarchical regression tree of Figure 6 of the Social index indicates that the most important factor is the student discussion about courses, topics and ideas with faculty members outside the classroom. The second most crucial factor for the high values of the Social index is students' relationships with peers while for the low values the relationships with their professors do matter. This is followed by the third important factor for both high and low values of the Social index, that is the collaboration with their fellow students in terms of the preparation for a course or exam.

\subsection{Economic Subfactor}

Figure 7 shows the hierarchical regression tree of the Economic index with interpretive variables of the items that compose it while Table 8 shows the four items and the corresponding variable importance percentages of the elements appearing on the optimal hierarchical tree imparted to the Economic index.

Table 8. Items of the Economic Index's Hierarchical Regression Tree

\begin{tabular}{lllc}
\hline No & Variable & Item description & $\begin{array}{c}\text { Variable } \\
\text { importance }\end{array}$ \\
\hline $\mathbf{1}$ & Needs Entertainment & Living conditions to meet the needs for entertainment. & 33.07 \\
$\mathbf{2}$ & Needs Basic & Living conditions to meet basic needs. & 24.66 \\
$\mathbf{3}$ & Needs Education & Living conditions to meet the needs for education and training. & 16.28 \\
$\mathbf{4}$ & Needs Housing & Living conditions to satisfy housing needs. & 15.96 \\
\hline
\end{tabular}

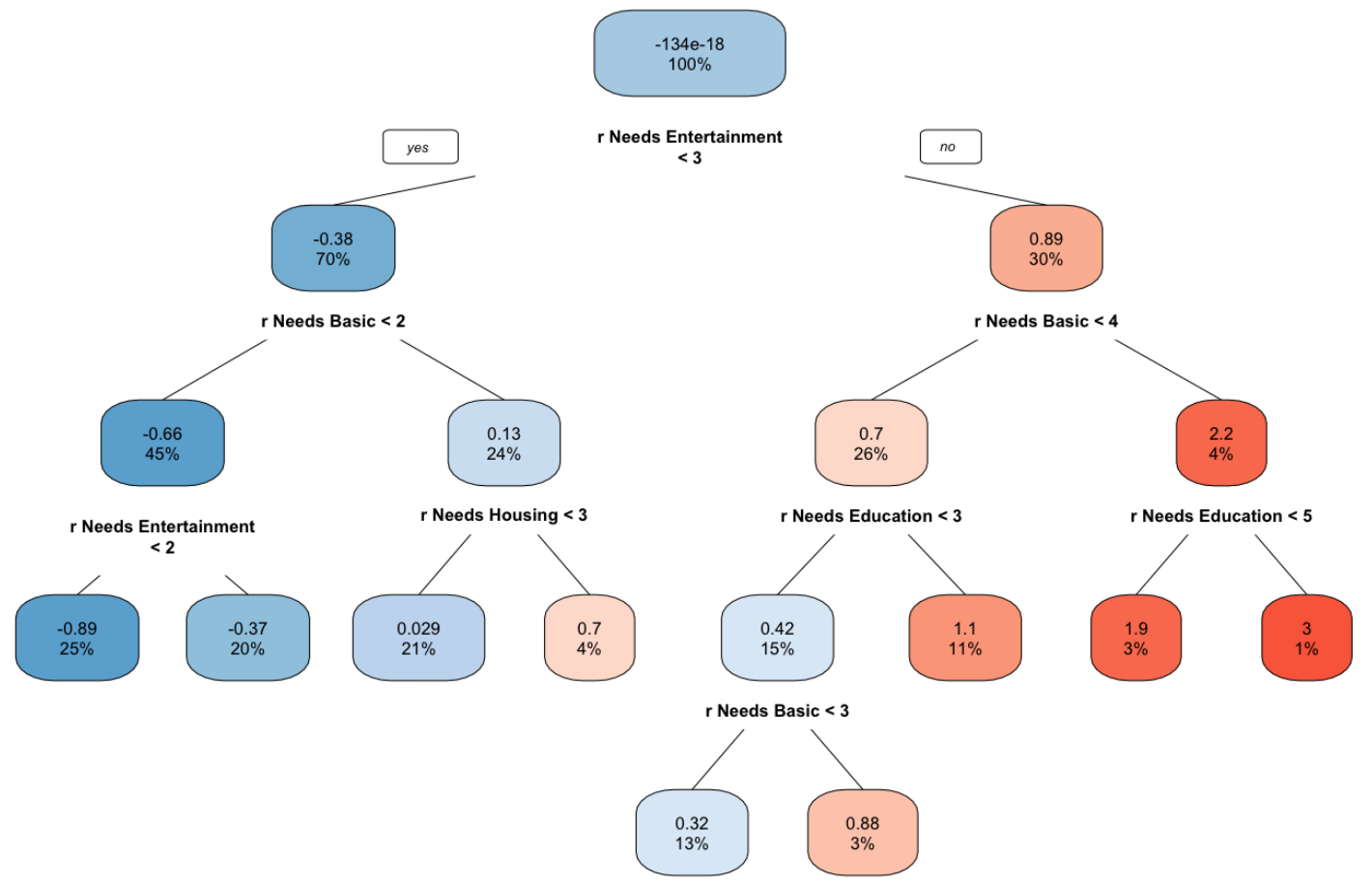

Figure 7. Hierarchical Regression Tree for the Economic Indicator 


\section{Macrothink}

According to the hierarchical regression tree presented in Figure 7, the most significant factor is the satisfaction with the standard of living to meet entertainment needs. The second most significant factor for both the high and low values of the Economic index, is the satisfaction with the standard of living to meet basic needs. This is followed by the satisfaction with the standard of living to meet the needs for education and training while for the low values the satisfaction with the standard of living to meet the housing needs does matter.

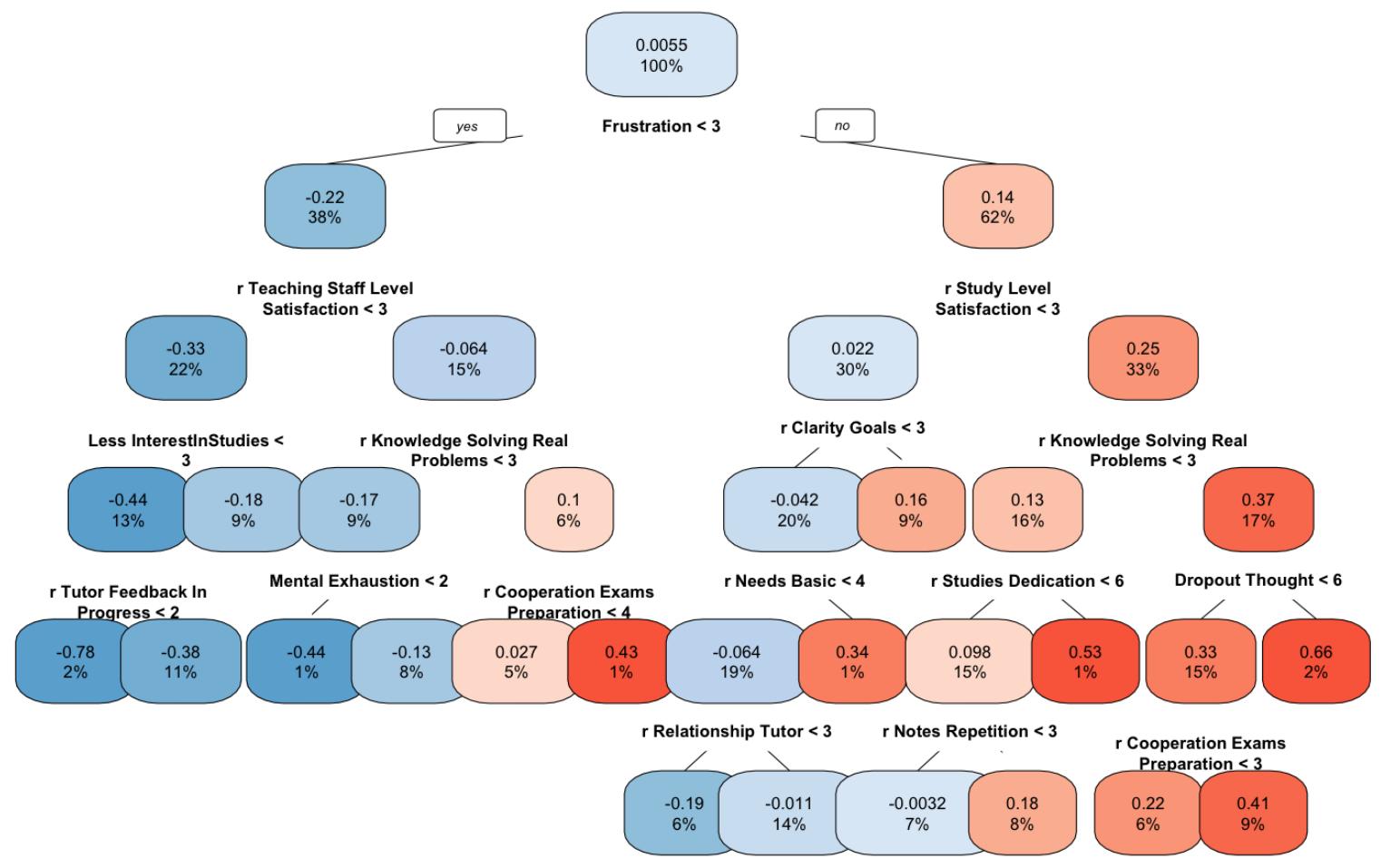

Figure 8. Hierarchical Regression Tree of the Dropout Indicator

On overall a hierarchical regression tree was applied to determine the contribution of the items involved in the interpretation of the Dropout index, as presented in Figure 8 where the Dropout index:

- Increases when the student feels frustrated with his/her studies, the objectives and requirements of the courses are not adequately explained, the university does not provide he/she with the skills to solve real complex problems and when the student loses interest in his/her studies through the time. This combination of factors occurs in the $4 \%$ of students. It is also noteworthy, that if the latter factor (declining interest in studies) is excluded, then the remaining sequence of factors applies to $15 \%$ of students, with an average Dropout index of 0.36 .

- Decreases when students do not feel frustrated with the studies, are satisfied with the level of teaching, have no diminished interest during their studies and receive adequate feedback from the professors on the tasks assigned to them. 


\section{Discussion}

In literature the research highlights the diverse factors affecting a student's decision to dropout or persist. It also places emphasis on the categorization off the influential factors in the context of a thorough analysis of the phenomenon (Adam \& Gaither, 2005; Alban \& Mauricio, 2019; Berge \& Huang, 2004; Díaz \& De León, 2016; Kim \& Kim, 2018; Kori et al., 2015; Yorke \& Thomas, 2003). While students' dropout is considered as a major international problem there seems no one widely acceptable system to deal with it insofar due to multi-dimensionality and the particular complexity of the phenomenon. In addition, it is important to recall the issue that Bardach et al. (2019) poses about the need factors interacting towards dropout prediction to be further enlightened and analyzed (Bardach et al., 2019).

In respect to the above and regardless to the first research question of this work, it emerged that student dropout is not the result of a single factor effect but the result of a sequence of factors that are indeed hierarchically dependent on each other. Furthermore, from this effort it arises that the most significant factor in terms of its influence on the tendency to dropout of studies is the Academic. The high values of this factorial group are affected by the students' satisfaction with the educational level, the provision with knowledge and skills to solve complex real-world problems and the success in passing half or more of their courses.

The Personal set of factors follows in sequence where its high values are provoked by the level of students' frustration with their studies, the thought of giving up, the rare repetition of their reading notes and the diminishing interest in their studies. In addition, from this research it emerged that on the third level of the factorial influence on students' tendency to dropout appear both the Academic and the Personal factor where the aggravation of their values provokes further increase to the dropout index.

As far as the Institutional factor is concerned, this appears on the fourth level of impact where its values are affected by students' satisfaction with the infrastructure facilities, the level of university assistance towards their academic success and simultaneously with the university emphasis's on activities in the campus.

In respect to the second research question, this work indicates the significance of the university school in regards to the diversity in the sequence of the factors influencing students' tendency to dropout. In particular, the sequence where the Personal factor displays the leading role followed by the Academic one dominates in all Schools with one single exception; the School of Humanities and Social Sciences where the sequence is reversed. Additionally, this work highlights one subfactor as extremely significant towards students' tendency to dropout appearing indeed in all Schools and that is the frustration a student may perceive from his/her studies.

Nevertheless, the research was conducted on "active" students and therefore, measures only the tendency to dropout and this can be considered a limitation. Thus, this research in future could be supplemented with a sample of students who have already dropped out in order to compare the dropout rate between active students and those who have already dropped out. 


\section{Conclusion}

On overall under the spectrum of dropout phenomenon' complexity the findings of this work could be useful on a theoretical and practical basis; the accomplishment of the research's dual purpose could enlighten in further the intercorrelations among the factorial categories affecting student's dropout tendency via the methodology of hierarchical regression trees indicating additionally their different sequences per School.

Furthermore, it may practically orientate university policies towards the development of a system for monitoring and supporting students' progress with an emphasis on the distinct traits of the student population and its different characteristics per School. Therefore, it is of importance that one university is aware of the different factors and their different sequences affecting student's tendency to dropout per School. In this way, a university could capture more effectively students' tendency to dropout of studies examining the different reasons existing in different Schools as well as the common ones. Therefore, the centralized concept of processes and structures appears not to be the most effectual scheme. Instead, the policies could be decentralized on School level with respect to the central mission on institutional level.

\section{References}

Adam, A. J., \& Gaither, G. H. (2005). Retention in higher education: A selective resource guide. New Directions for Institutional Research, 2005(125), 107-122. https://doi.org/10.1002/ir.142

Aina, C. (2013). Parental background and university dropout in Italy. Higher Education, 65(4), 437-456. https://doi.org/10.1007/s10734-012-9554-z

Alban, M., \& Mauricio, D. (2019). Predicting university dropout through data mining: a systematic literature. Indian Journal of Science and Technology, 12(4), 1-12. https://doi.org/10.17485/ijst/2019/v12i4/139729

Astin, A. W. (1975). Preventing Students from Dropping Out. Jossey-Bass. Retrieved from http://lib.ugent.be/catalog/rug01:001365957

Austin, E. J., Evans, P., Goldwater, R., \& Potter, V. (2005). A preliminary study of emotional intelligence, empathy and exam performance in first year medical students. Personality and Individual Differences, 39(8), 1395-1405. https://doi.org/10.1016/j.paid.2005.04.014

Balias, S., Kamarianos, I., Kiprianos, P., \& Stamelos, G. (2016). University, Economy and Democracy: transformations and challenges. The case of Greece (S. Balias \& I. Kamarianos (eds.)). Lambert Academic Publishing, Germany.

Bardach, L., Lüftenegger, M., Oczlon, S., Spiel, C., \& Schober, B. (2019). Context-related problems and university students' dropout intentions - the buffering effect of personal best goals. European Journal of Psychology of Education, 1-17. https://doi.org/10.1007/s10212-019-00433-9 
Berge, Z. L., \& Huang, Y.-P. (2004). 13: 5 A model for sustainable student retention: A holistic perspective on the student dropout problem with special attention to e-Learning. Retrieved from www. Researchgate. Net/Profile/Zane_Berge/Publication

Brackett, M. A., Rivers, S. E., Shiffman, S., Lerner, N., \& Salovey, P. E. (2006). Relating emotional abilities to social functioning: a comparison of self-report and performance measures of emotional intelligence. Journal of Personality and Social Psychology, 91(4), 780-795. https://doi.org/10.1037/0022-3514.91.4.780

Braxton, J. M., Milem, J. F., \& Sullivan, A. S. (2000). The influence of active learning on the college student departure process: Toward a revision of Tinto's theory. The Journal of Higher Education, 71(5), 569-590. https://doi.org/10.1080/00221546.2000.11778853

Breiman, L. (2017). Classification and regression trees. Routledge.

Bresó, E., Salanova, M., \& Schaufeli, W. B. (2007). In search of the "third dimension" of burnout: Efficacy or inefficacy? Applied Psychology, 56(3), 460-478. https://doi.org/10.1111/j.1464-0597.2007.00290.x

Casanova, J. R., Cervero Fernández-Castañón, A., Núñez Pérez, J. C., Almeida, L. S., \& Bernardo Gutiérrez, A. B. (2018). Factors that determine the persistence and dropout of university students $=$ Factores determinantes de la permanencia y abandono de los estudiantes universitarios. Psicothema, 30(4), 408-414. https://doi.org/10.7334/psicothema2018.155

Commission/EACEA/Eurydice, E. (2013). Education and Training in Europe 2020. Responses from the EU Member States. In Eurydice Report. Eurydice Brussels. Retrieved from http://hdl.voced.edu.au/10707/293181

Communiqué, B. (2005). The European higher education area-achieving the goals. Communiqué of the Conference of European Ministers Responsible for Higher Education, 19-20.

Communiqué, B. (2003). Realising the European higher education area.

Communiqué, B. (2012). Making the most of our potential: Consolidating the European Higher Education Area. Conference of Ministers Responsible for Higher Education, Bucharest, 26-27.

Communiqué, L. (2009). The Bologna Process 2020-The European Higher Education Area in the new decade. Communiqué of the Conference of European Ministers Responsible for Higher Education.

Communiqué, L. (2007). Towards the European Higher Education Area: responding to challenges in a globalised world. London.

Communiqué, P. (2018). Paris Communiqué. Unpublished Manuscript. Accessed October, 10, 2018.

Communiqué, P. (2001). Towards the European higher education area. communiqué of the 
meeting of european ministers in charge of higher education in prague on may 19th 2001. European Union, Brussels. Retrieved from www. Bologna-Berlin2003. de/Pdf/Prague_CommuniquTheta. Pdf

Communiqué, Y. (2015). Yerevan Communiqué. Conference of Ministers Responsible for Higher Education, Yerevan, 14-15.

Demerouti, E., \& Nachreiner, F. (1998). Zur Spezifität von burnout für dienstleistungsberufe: fakt oder artefakt. Zeitschrift Fur Arbeitswissenschaft, 52, 82-89.

Díaz, P., \& De León, A. T. (2016). Design and Validation of a Questionnaire to Analyze University Dropout-CADES. World, 3(2), 267-280. https://doi.org/10.22158/wjer.v3n2p267

Drennan, J., O’Reilly, S., O’Connor, M., O’Driscoll, C., Patterson, V., Purser, L., \& Murray, J. (2014). The irish survey of student engagement. In H. Coates \& A. McCormick (Eds.), Engaging university students (pp. 109-125). Springer. https://doi.org/10.1007/978-981-4585-63-7_8

Ewell, P. T. (2010). The US national survey of student engagement (NSSE). In D. Dill \& M. Beerkens (Eds.), Public policy for academic quality (pp. 83-97). Springer. https://doi.org/10.1007/978-90-481-3754-1_5

Fredricks, J. A., Blumenfeld, P. C., \& Paris, A. H. (2004). School engagement: Potential of the concept, state of the evidence. Review of Educational Research, 74(1), 59-109. https://doi.org/10.3102/346543074001059

Fredricks, J. A., \& McColskey, W. (2012). The measurement of student engagement: A comparative analysis of various methods and student self-report instruments. In $\mathrm{S}$. Christenson, A. Reschly, \& C. Wylie (Eds.), Handbook of research on student engagement (pp. 763-782). Springer. https://doi.org/10.1007/978-1-4614-2018-7_37

García de Fanelli, A., \& Adrogué de Deane, C. (2015). Abandono de los estudios universitarios: dimensión, factores asociados y desafíos para la política pública. Revista Fuentes, 16, 85-106.

Goleman, D., Boyatzis, R. E., \& McKee, A. (2002). The new leaders: Transforming the art of leadership into the science of results. Little, Brown London.

Goleman, D., Boyatzis, R. E., \& McKee, A. (2013). Primal leadership: Unleashing the power of emotional intelligence. Harvard Business Press.

Gury, N. (2011). Dropping out of higher education in France: a micro-economic approach using survival analysis. Education Economics, 19(1), 51-64. https://doi.org/10.1080/09645290902796357

Handelsman, M. M., Briggs, W. L., Sullivan, N., \& Towler, A. (2005). A measure of college student course engagement. The Journal of Educational Research, 98(3), 184-192. https://doi.org/10.3200/JOER.98.3.184-192 
Hellenic Statistical Authority. (2015). Table 3: Higher education - Number of Students by Gender, Semester, Faculty, Educational Institute. Hellenic Statistical Authority. Retrieved from http://www.statistics.gr/el/statistics/-/publication/SED33/2015

Heublein, U. (2014). Student Drop-out from German Higher Education Institutions. European Journal of Education, 49(4), 497-513. https://doi.org/10.1111/ejed.12097

Hu, Q., \& Schaufeli, W. B. (2009). The factorial validity of the Maslach burnout inventory-student survey in China. Psychological Reports, 105(2), 394-408. https://doi.org/10.2466\%2FPR0.105.2.394-408

Kehm, B. M., Larsen, M. R., \& Sommersel, H. B. (2019). Student dropout from universities in Europe: A review of empirical literature. Hungarian Educational Research Journal, 9(2), 147-164. https://doi.org/10.1556/063.9.2019.1.18

Kim, D., \& Kim, S. (2018). Sustainable education: analyzing the determinants of university student dropout by nonlinear panel data models. Sustainability, 10(4), 954. http://dx.doi.org/10.3390/su10040954

Kokkinos, C. M. (2006). Factor structure and psychometric properties of the Maslach Burnout Inventory-Educators Survey among elementary and secondary school teachers in Cyprus. Stress and Health, 22(1), 25-33. https://doi.org/10.1002/smi.1079

Kori, K., Pedaste, M., Tõnisson, E., Palts, T., Altin, H., Rantsus, R., Sell, R., Murtazin, K., \& Rüütmann, T. (2015). First-year dropout in ICT studies. 2015 IEEE Global Engineering Education Conference, (EDUCON), 437-445. https://doi.org/10.1109/EDUCON.2015.7096008

Larsen, M. R., Sommersel, H. B., \& Larsen, M. S. (2013). Evidence on dropout phenomena at universities. Danish Clearinghouse for educational research Copenhagen. Retrieved from

http://edu.au.dk/en/research/research-areas/danish-clearinghouse-for-educational-researc $\mathrm{h} /$

Limesurvey, G. (2019). LimeSurvey: An Open Source survey tool. Limesurvey GmbH. Retrieved from http://www.limesurvey.org

McCoy, S., \& Byrne, D. (2017). Student retention in higher education. In J. Cullinan \& D. Flannery (Eds.), Economic insights on higher education policy in Ireland (pp. 111-141). Springer. https://doi.org/10.1007/978-3-319-48553-9_5

McKenzie, K., \& Schweitzer, R. (2001). Who succeeds at university? Factors predicting academic performance in first year Australian university students. Higher Education Research \& Development, 20(1), 21-33. https://doi.org/10.1080/07924360120043621

Montmarquette, C., Mahseredjian, S., \& Houle, R. (2001). The determinants of university dropouts: a bivariate probability model with sample selection. Economics of Education Review, 20(5), 475-484. https://doi.org/10.1016/S0272-7757(00)00029-7 
Mujica, A. D., Villalobos, M. V. P., Gutiérrez, A. B. B., Fernández-Castañón, A. C., \& González-Pienda, J. A. (2019). Affective and cognitive variables involved in structural prediction of university dropout. Psicothema, 31(4), 429-436. https://doi.org/10.7334/psicothema2019.124

Need, A., \& De Jong, U. (1998). De invloed van opleiding op studieresultaten en studieuitval na een jaar studeren in het hoger onderwijs [The influence of the department on achievement en drop out after one year of study in higher education]. Sociaal Wetenschappelijke Studiedagen, Amsterdam, April 16 ${ }^{\text {th }}-17$ th, The Netherlands.

Petrides, K. V. (2009). Psychometric properties of the trait emotional intelligence questionnaire (TEIQue). In J. D. A. Parker, D. H. Saklofske, \& C. Stough (Eds.), Assessing emotional intelligence (pp. 85-101). Springer. https://doi.org/10.1007/978-0-387-88370-0_5

Pike, G. R., \& Saupe, J. L. (2002). Does high school matter? An analysis of three methods of predicting first-year grades. Research in Higher Education, 43(2), 187-207. https://doi.org/10.1023/A:1014419724092

Reis, D., Xanthopoulou, D., \& Tsaousis, I. (2015). Measuring job and academic burnout with the Oldenburg Burnout Inventory (OLBI): Factorial invariance across samples and countries. Burnout Research, 2(1), 8-18. https://doi.org/https://doi.org/10.1016/j.burn.2014.11.001

Roso-Bas, F., Jiménez, A. P., \& García-Buades, E. (2016). Emotional variables, dropout and academic performance in Spanish nursing students. Nurse Education Today, 37, 53-58. https://doi.org/10.1016/j.nedt.2015.11.021

Rupp, A. A., \& Zumbo, B. D. (2004). A note on how to quantify and report whether IRT parameter invariance holds: When Pearson correlations are not enough. Educational and $\begin{array}{lll}\text { Psychological } \quad \text { Measurement, } & \text { 64(4), }\end{array}$ https://doi.org/10.1177/0013164403261051

Schutte, N. S., Malouff, J. M., Hall, L. E., Haggerty, D. J., Cooper, J. T., Golden, C. J., \& Dornheim, L. (1998). Development and validation of a measure of emotional intelligence. Personality and Individual Differences, 25(2), 167-177.

Shankland, R., Genolini, C., França, L. R., Guelfi, J.-D., \& Ionescu, S. (2010). Student adjustment to higher education: the role of alternative educational pathways in coping with the demands of student life. Higher Education, 59(3), 353-366. https://doi.org/10.1007/s10734-009-9252-7

Spady, W. G. (1971). Dropouts from higher education: Toward an empirical model. Interchange, 2(3), 38-62. $\quad$ Retrieved from https://link.springer.com/content/pdf/10.1007/BF02282469.pdf

Stratton, L. S., O’Toole, D. M., \& Wetzel, J. N. (2008). A multinomial logit model of college stopout and dropout behavior. Economics of Education Review. 
https://doi.org/10.1016/j.econedurev.2007.04.003

Suhre, C. J. M., Jansen, E. P. W. A., \& Harskamp, E. G. (2007). Impact of degree program satisfaction on the persistence of college students. Higher Education, 54(2), 207-226. https://doi.org/10.1007/s10734-005-2376-5

Therneau, T., Atkinson, B., \& Ripley, B. (2018). rpart: Recursive partitioning and regression trees (R package). Retrieved from https://cran.r-project.org/package=rpart

Tinto, V. (1975). Dropout from higher education: A theoretical synthesis of recent research. Review of Educational Research, 45(1), 89-125. https://doi.org/https://doi.org/10.3102\%2F00346543045001089

Tinto, V. (1998). Colleges as communities: Taking research on student persistence seriously. The Review of Higher Education, 21(2), 167-177.

Tinto, V. (2006). Research and practice of student retention: What next? Journal of College Student Retention: Research, Theory \& Practice, 8(1), 1-19. https://doi.org/10.2190\%2F4YNU-4TMB-22DJ-AN4W

Tinto, V. (2017). Through the eyes of students. Journal of College Student Retention: $\begin{array}{llll}\text { Research, } \quad \text { Theory } \quad \text { \& } & \text { Practice, } & \text { 19(3), }\end{array}$ https://doi.org/10.1177/1521025115621917

Van Bragt, C. A. C., Bakx, A. W. E. A., Bergen, T. C. M., \& Croon, M. A. (2011). Looking for students' personal characteristics predicting study outcome. Higher Education, 61(1), 59-75. https://doi.org/10.1007/s10734-010-9325-7

Van Bragt, C. A. C., Bakx, A. W. E. A., Van der Sanden, J. M. M., \& Croon, M. A. (2007). Students' approaches to learning when entering higher education: Differences between students with senior general secondary and senior secondary educational backgrounds. Learning and Individual Differences, 17(1), 83-96. https://doi.org/10.1016/j.lindif.2007.02.003

Van der Hulst, M., \& Jansen, E. (2002). Effects of curriculum organisation on study progress in engineering studies. Higher Education, 43(4), 489-506. https://doi.org/10.1023/A:1015207706917

Yorke, M., \& Thomas, L. (2003). Improving the retention of students from lower socio-economic groups. Journal of Higher Education Policy and Management, 25(1), 63-74. https://doi.org/10.1080/13600800305737

Zanon, C., Hutz, C. S., Yoo, H., \& Hambleton, R. K. (2016). An application of item response theory to psychological test development. Psicologia: Reflexao e Critica, 29(1). https://doi.org/10.1186/s41155-016-0040-x

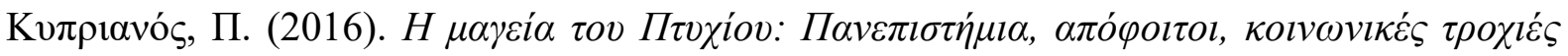

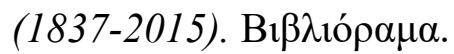

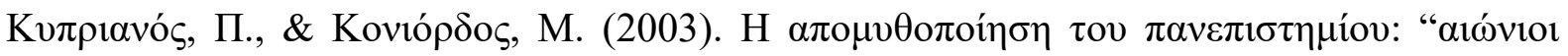




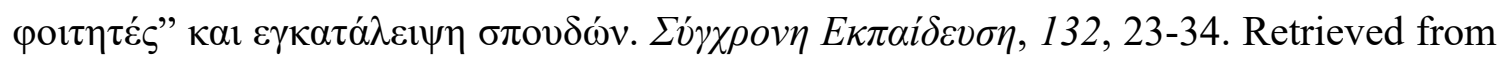

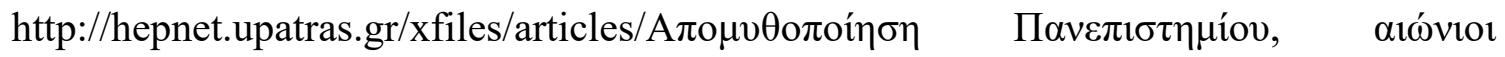

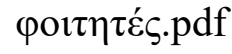

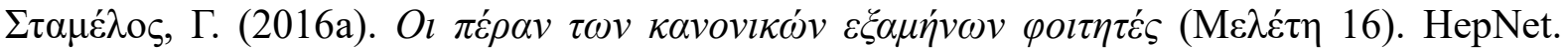
https://doi.org/10.13140/RG.2.1.4878.1847

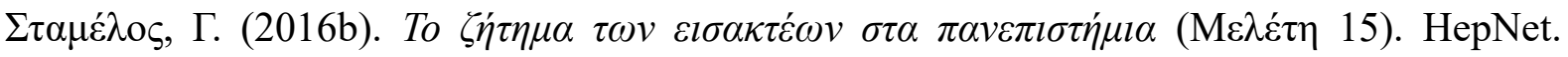
Retrieved from http://hepnet.upatras.gr/xfiles/pubs/Meletes_Reports/Meleti15.pdf

\section{Copyright Disclaimer}

Copyright for this article is retained by the author(s), with first publication rights granted to the journal.

This is an open-access article distributed under the terms and conditions of the Creative Commons Attribution license (http://creativecommons.org/licenses/by/3.0/). 